\title{
Insights from Students' Perspective of 9GAG Humorous Memes Used in EFL Classroom
}

\author{
Budi Eko Pranoto*, Suprayogi \\ Faculty of Arts and Education, Universitas Teknokrat Indonesia \\ ${ }^{*}$ Corresponding author. Email: budiekoranoto@teknokrat.ac.id
}

\begin{abstract}
Funny memes, circulating on the internet, are easily accessible media to produce laughter in any setting, including teaching-learning setting. The laughter resulted can be crucial to tackle barriers of communication for educational purposes. This paper is aimed at revealing EFL learners' perception of funny memes taken from 9GAG Apps used during teaching-learning session in EFL context. It is also set to seek the influence of humor in building learners' engagement in classroom activities. This qualitative research employs questionnaire and observation as the instruments to collect the data from 30 adults EFL learners. These EFL learners have multi-background (gender, intelligence level, and social) which is beneficial to the objectivity of the perception. The results revealed that the majority of EFL learners believed that humor could cheer them during teaching-learning session of English and make them less stressful. Humor also assists to build a better chemistry between teacher and EFL learners; making them remember and understand the lesson better. The last, it also encourages EFL learners to be more actively involved in the classroom activities. Nevertheless, some constraints arise during the application of humor taken from 9GAG. English teacher needs to understand the characteristics of learners and their interests prior to implementing this pedagogical technique. Due to the nature of humor that is segmented, the right humorous material would be more likely acceptable, and it would cause emotional and psychological impact that can develop EFL learners' learning ability.
\end{abstract}

Keywords: 9GAG, EFL, humor, memes, perceptions

\section{INTRODUCTION}

The activity of studying must be designed to achieve the essence of learning that is possessing the core knowledge of subject. In reality, many thinks that these words have the same meaning. These words are related and often used to refer to the same process, but they linguistically serve for different ideas; learning is the phase where knowledge is gained by some acts of studying (Carr, 2017). This ideal condition, targeted for learners, might be achieved through specially designed pedagogical measures enabling learners to be motivated, encouraged, and motivated. Specially designed pedagogical measures refer to real-life situation during teaching-learning session which is believed to be essential in assisting learners in learning language (Faharani and Abdollahi, 2018, p.205). Many teachers are unaware of factors that can establish that setting. One of the factors is called humor. Humor has the power to create a more relaxing classroom setting atmosphere affecting students' feeling, lower their anxiety and make them more motivated (Wagner \& Urios-Aparisi, 2011).
In this case, appropriate humor does not only transform EFL classroom setting into a fun one but also motivates and encourages students to be more active during learning session (Fata, Komariah, \& Irfandy, 2018). Humor as part of pedagogical tool implemented in EFL classroom is not a new thing for educators (Askildson, 2005; Azizinezhad \& Hashemi, 2011; Davis, 2014; Farahani \& Abdollahi, 2018; Syafiq, 2012). But there is still a high degree of reluctancy in using humor as part of the pedagogical measures.

Using humor in classroom is impactful in escalating class' atmosphere into a relaxing, comforting, and tension-reducing setting. Furthermore, it not only maintains/increases learners' interest and mood, but also humanly maintains the teacher's image (the teacher is not being degraded though he/she produces/uses humor in his/her classes). Unfortunately, teachers are afraid of using humor in the class because they believe they may be losing their authority; therefore, it needs to be put away (Azizinezhad \& Hashemi, 2011). Stroud (2013) in Hibatullah and Ardlillah (2019) investigated that giving 
an overdose joke/humor leads to a lack of seriousness of learning atmosphere. Interestingly, this assumption is contrast with findings from other studies. Recently, many researchers have concluded that humor could be one of the effective approaches in creating a lively classroom situation (Tunisa et al., 2019; Jatiyasa, 2019). Recent research by Farahani and Abdollahi (2018) stated that humor incorporated in English classroom improves EFL learners speaking ability and their willingness to communicate. Meanwhile Rima (2009), Mary (2008), Hoang (2014), and Antonio (2001) in (Fata et al., 2018) stated that humor added to English class would help students to possess higher understanding in mastering new language, because it is believed that the laughter resulted from humor is the crucial aspect to tackle barriers of communication for educational purposes. Glenn (2003) also added that these barriers include the absence of information retention, lack of attention to the topic discussed, and an unpleasant learning setting.

Interestingly, Al-Duleimi and Aziz (2016) said that in language learning environments, the use of humor can not only serve as a means of amusement but it is a matter of rehearsal which entails not necessarily fun but a means of developing linguistic skills. There are many sources of humor available, and one of the widely circulated applications is called $9 G A G$. $9 G A G$ is a social media that contains humorous contents on various issues: politics, sports, social, music, and others. 9GAG content in the form of memes is naturally narrated in English, so it is considered relevant to be incorporated to EFL class and be observed it effect to the learners' perception.

The perception of language learners is considered essential in defining pedagogical measures in EFL context. Teachers around the globe are working endlessly to formulate reliable pedagogical measure in teaching English as foreign language (Phakiti, 2006). In teaching EFL, many teachers try to combine teaching technique and numerous social aspects, one of them is humor. Many believes that a sense of humor transforms the classroom environment becoming lively and reduces anxiety by providing an unobstructed and enjoyable atmosphere (Al-Duleimi \& Aziz, 2016). Also, they believe that humor positively. Marlon (2008) in (Fata et al., 2018) claimed that the utilization of humor in EFL setting resonates many positive outcomes. It makes the students feeling relax, reduces tension and makes them less stressful which results to the effectiveness of learning second language (Hibatullah \& Ardlillah, 2019). S Elliot once said "Humor is also a way of saying serious things". This needs to be maximized in the realm of learning in tertiary institutions to create a pleasant learning atmosphere. According to Sheinowizt as quoted by Darmansyah (2012, p. 66), "Humor is a funny quality of someone who is ridiculous and entertaining." According to Darmansyah (2012, pp. 102-106), there are five benefits of humor in learning, namely: (1) humor as a student's attention grabber; (2) humor helps reduce boredom in learning; (3) humor helps relieve tension in the classroom; (4) humor helps overcome physical and mental fatigue in learning; and (5) humor to facilitate communication and interaction.

Interaction also means participation which is crucially important in the communicative (speaking) classroom where the emphasis is on real oral communication, group task, and interaction. Humor can be one way to involve students, who generally feel worried and nervous, in class activities to express their thoughts in a foreign language (Provine, 2002). Kristmanson (2000) emphasizes the need to create a friendly atmosphere for language learning. Humor is perhaps one of the most original and universal speech acts in human discourse (Askildson, 2005). As the consequence, the use of humor in the context of EFL pedagogy offers significant advantages for language teachers and learners in speaking classes under EFL context. However, in higher education, humor has not been fully maximized by the lecturers as a fun learning strategy to support communicative activities in the classroom. Therefore, this study aims to reveal the EFL learners' perception in regard to the integration of 9GAG's humor as teaching materials in EFL classroom.

\section{METHOD}

This research employed 30 participants of adult EFL learners who were taking English major in one of universities in Bandar Lampung. The students were assessed to reveal their view on the use of $9 \mathrm{GAG}$ humorous memes incorporated during teaching English session in EFL context. The problem in this research is formulated into how do EFL learners perceive 9GAG humorous memes incorporated in teaching English? This research is included as qualitative research which tries to add insights in innovative teaching method. In this type of research, the researcher obtains elaboration of peculiar phenomena and is prohibited to manipulate the results (Fata et al., 2018). As for the instrument, the researcher employed questionnaire, and also conducted an observation during the process. The data were collected from 30 university students taking English major. They have heterogenous background ranging from gender, speaking score (the score of the prerequisite subject taken previously), and social repertoire (organizations and activities they involve in outside the class). These backgrounds are intentionally selected to obtain natural response from the respondents during teaching and learning of English in EFL context. The questionnaire used in this research was adapted from Fata et al. (2018) that contains statements requiring the following responses: strongly agree, agree, neutral, strongly disagree, and disagree. Furthermore, the observation was conducted to collect the factual findings based on the learners' response against the incorporation of $9 G A G$ memes in teaching EFL. 


\section{FINDINGS AND DISCUSSION}

The results of this study are comparable with the results of the previous studies reviewed in this study. This comparison is necessarily made to provide insight of incorporating specific genre of universal humor to English class. Previous studies generally examined the effect of humor on learning a second/foreign language, the students' perception on humor, and types of humor implemented by teachers in EFL classroom. But that research did not mention the specific type of humor used as the material. Meanwhile in this research, the researcher employed specific humorous memes taken from $9 G A G$ apps. The data distribution refers to the learners' response comprising their perceptions about 9GAG memes incorporated during teaching EFL. The questionnaire is structured into three parts: the use of humor in teaching EFL, the advantages of humor, and the perception towards humor. EFL learners' responses are distributed in the Table 1.

Table 1 reveals that learners of English mostly convey their positive response to the incorporation of humorous $9 G A G$ memes during teaching English session. As this research is a preliminary research for a bigger scope, the writer decided to combine the agreement table resulted from the distribution of questionnaire using Likert Scale. In the table above, the "Strongly Agree" and "Agree" are combined into one, and "Disagree" and "Strongly Disagree" are also combined into one. The "Undecided" column is not listed because no respondent responded to this option. The positive response is significantly comprising $80 \%$ or more of the total respondents. This positive response includes student's engagement, participation, assistance, and relevance. They also claim that the incorporation of humor in the class makes the gap between teacher and learner becomes smaller and the teacher's image is also maintained. The effects of humor to the ability of learners in comprehending English material are also positively found. The learners' response also draws the assumption of teacher-learner relation, and also teacher's image in the class.

Based on the data calculation on learners' response on "9GAG humorous memes reduce stress", it is found that all of the 30 learners $(100 \%)$ claimed that those $9 G A G$ memes could relief their stress during teaching-learning session. This claim is based on the learners' opinion that humor ( $9 G A G$ memes) mediates the relation among class participants, most importantly with the teacher. Therefore, it can be presumed that humor builds a lively situation which support the activeness of the learners. A close relationship among class participants leads to effectiveness learning activities resulting in the improvement of learners' ability, such speaking ability and their willingness to communicate (Farahani \& Abdollahi, 2018). It is assumed that close relationship makes the learners feel comfortable in exchanging their thought and opinion without being afraid of anything.
Table 1. Data Distribution of Learners' Response

\begin{tabular}{|c|c|c|}
\hline \multirow{2}{*}{ Questions items } & \multicolumn{2}{|c|}{$\begin{array}{l}\text { Students' } \\
\text { response }\end{array}$} \\
\hline & agree & disagree \\
\hline $\begin{array}{l}\text { 9GAG humorous memes reduces } \\
\text { stress }\end{array}$ & $100 \%$ & - \\
\hline $\begin{array}{l}9 G A G \text { humorous memes helps } \\
\text { learners to remember the lesson }\end{array}$ & $90 \%$ & $10 \%$ \\
\hline $\begin{array}{l}9 G A G \text { humorous memes engages } \\
\text { learners' participation in classroom }\end{array}$ & $80 \%$ & $20 \%$ \\
\hline $\begin{array}{l}9 G A G \text { humorous memes mainly } \\
\text { promotes learners' } \\
\text { participation }\end{array}$ & $85 \%$ & $15 \%$ \\
\hline $\begin{array}{l}9 G A G \text { humorous memes eases } \\
\text { English learning }\end{array}$ & $88 \%$ & $12 \%$ \\
\hline $\begin{array}{l}\text { The relevance of } 9 G A G \text { humorous } \\
\text { memes }\end{array}$ & $100 \%$ & - \\
\hline $\begin{array}{l}\text { Humorous teacher as a clown, } \\
\text { comedian or funny teacher }\end{array}$ & $5 \%$ & $95 \%$ \\
\hline $\begin{array}{l}\text { Humor creates gap between teacher } \\
\text { and students }\end{array}$ & $7 \%$ & $93 \%$ \\
\hline
\end{tabular}

The analysis of the questionnaires indicated that $100 \%$ of students apprised that $9 G A G$ humorous memes reduce stress. This is in line with Wagner and UriosAparisi, (2011) that humor relaxes classroom setting atmosphere affecting students' feeling, lower their anxiety and make them more motivated. This finding also affirms the initial assumption that humor has the ability to create a real-life situation in the class.

On the question of " $9 G A G$ humorous memes helps learners to remember the lesson", the distribution of the data presents that only $10 \%$ of the learners disagree that those humorous memes assist them in remembering the lesson better. On the other hand, $90 \%$ of them believed that those memes are crucially helping them to remember the English lesson better. This condition implies that humorous memes serve an important role in ensuring that the material delivered is well understood by the learners. This claim affirms the claim that learners speaking ability is improved by the incorporation of humor in English class (Farahani \& Abdollahi, 2018). This is also in line with Rima (2009), Mary (2008), Hoang (2014), and Antonio (2001) in (Fata et al., 2018) that humor help to ease students to master new language. This finding is also significantly supported by the fact that those $9 G A G$ humorous memes are incorporated to an English class. It rises another possible research question about the impact of humor incorporated to other subjects.

Based on the data calculation and analysis, $80 \%$ of the EFL learners claimed that $9 G A G$ humorous memes engaged learners' participation in classroom by reducing unfriendliness and encouraging cooperation and learning motivation, while the rest $20 \%$ did not consider humorous memes as something that could engage them in participating the learning activities. This finding reveals that EFL learners are more willing to participate in the activities when the situation is fun and enjoyable. 
This also affirms the universal opinion that we will perform better we are comfortable with the environment. Furthermore, this condition is also in line with learners' perception stating that " $9 G A G$ humorous memes mainly promotes learners' active participation". $85 \%$ of the learners believed that particularly selected humorous memes are helpful in making them more motivated. This finding supports Fata et al. (2018) claim stating that humor motivates and encourages students to be more active during learning session. By this condition, we, as teacher, are relieved knowing that learners are comfortable and highly motivated to perform. Therefore, the learning goals of the subject can be achieved at the end of the period.

The following finding on the question " $9 G A G$ humorous memes eases English learning" also support those findings elaborated above. The majority of EFL learners $(88 \%)$ believed that the incorporation of $9 G A G$ humorous memes to the class eases them in learning English. This claim is resulted from the nature of $9 G A G$ memes that are naturally narrated in English which are considered to be helpful. Only $12 \%$ of the total learners who considered that humorous $9 G A G$ memes were not helpful in easing the learning activity. This claim affirms the claim that learners speaking ability is improved by the incorporation of humor in English class (Farahani \& Abdollahi, 2018). This is also in line with Rima (2009), Mary (2008), Hoang (2014), and Antonio (2001) (as cited in Fata et al., 2018) that humor help to ease students to master new language.

The analysis result of the relevance of $9 G A G$ humorous memes to the EFL setting shown that all of the EFL learners $(100 \%)$ agreed that they are relevant to be incorporated in English class. Similar to the previous finding, the relevance of $9 G A G$ humorous memes is seen from the narration of the memes that is written in English. The memes were also particularly selected based on the topic discussed in the class. The humorous contents taken are about various issues: politics, sports, social, music, and others. 9GAG contents in the form of memes are naturally narrated in English, so it is considered relevant to be incorporated to EFL class. The learners considered the relevance of those memes is also because the memes are particularly crafted and selected in accordance with the subject discussed. Also, during the class, the learners are also asked to elaborate the joke orally.

In term of teachers' reluctancy in utilizing humor in EFL setting, the main concern is on the image of the teacher. Many assumed that teacher who produced jokes during teaching would make them less respected. Many of them are afraid of using humor in the class because they believe they may be losing their authority; therefore, it needs to be put away (Azizinezhad \& Hashemi, 2011). The finding is this research reveals that in response to the question "Humorous teacher as a clown, comedian or funny teacher", $5 \%$ of the total learners perceived the teacher as comedian. But the other $95 \%$ perceived the teacher who incorporated humor in the class as funny teacher, and they consider them as someone who can make the class becoming more enjoyable. This prejudice arises due to the idea that those who produces many jokes are considered as comedian; someone whose job is to entertain. Meanwhile, in the context of education, teacher is the one who teach.

In this research, the learners were also investigated the EFL learners to know their views on the possible negative effects implicated from the incorporation of humorous 9GAG memes in English classroom. The results showed that all the students said that they believed that humorous material given in English class would not cause any negative implication. But, two learners said that there's still a small possibility that learners might miscarried their closeness with the teacher by making some disrespectful actions (Fata et al., 2018), claimed that some students believed that humor could lead disrespect in English class. In this research, when the two respondents were questioned about their concern on the matter, they explained that teachers who produce many humors during teaching may be perceived as less-serious person. Therefore, it could lead disrespect in the class.

The finding about the assumption that "Humor creates gap between teacher and students" proves that those humor resulted from memes is significantly cut the distance and increase the proximity among participants of the class, especially with the teacher. Even so, there are some learners $(7 \%)$ who responded that humor incorporated to in English could not cut the gap among participants in English class. This finding is in contrast with a research conducted by Fata et al. (2018) which revealed that no students believed that humor could lead to negative implication in the sense of distance between learners and teachers in EFL context. Compared to Tunisa et al (2019), and Jatiyasa (2019), this research confirmed the findings. Their research affirmed that utilizing humor in EFL classroom is effective to create an effective learning setting, good for classroom atmosphere, and smooth relation between teachers and learners. Meanwhile, part of the result of this present research shows a significant development of speaking ability and willingness to communicate of EFL learners (Pranoto, \& Suprayogi, 2020). It is believed to be the causes of positive response from EFL learners to the integration of $9 \mathrm{GAG}$ humorous memes in the class. This significance development implicates that humor can also lead to an effective learning setting. Therefore, the results of this research are in accordance with Tunisa et al (2019), and Jatiyasa (2019) findings.

All of the findings reveal that it is reasonable to incorporate $9 G A G$ humorous memes as material in EFL class. Those humorous memes are relevant as part of an effective pedagogical measure since it can create an ideal learning environment which positively assists learners in 
comprehending the lesson and performing well. These findings confirmed numerous previous studies' claim on the miracle of humor as pedagogical tools for language learners.

\section{CONCLUSION}

Based on the results and discussion, it explicates that most of learners claim that humorous material could reduce their stress of learning English, develop a better relationship among learners and also teacher, make them learn the lesson better, encourage and motivate them to be more actively involved in classroom's activities. Therefore, humorous memes have potential pedagogic advantages if implemented correctly in English class. As suggestion to the teachers who are willing to incorporate humorous material in English class, they need to prepare that the memes selected needs to specially crafted and selected in accordance with the competence of the learners. It is due to the fact that some memes are strictly segmented which of course requires preliminary background to understand. A further research of EFL teachers' perception on the use of humor in EFL setting is advised as the comparison to student's perspective. It is also suggested to conduct a research on the effectiveness of incorporating humorous memes in other classes.

\section{REFERENCES}

Al-Duleimi, A. D. D., \& Aziz, R. N. (2016). Humor as EFL learning-teaching strategy. Journal of Education and Practice, 7(10), 105-115. https://search.ebscohost.com/login.aspx?direct=tru e\&db=eric\&AN=EJ1099483\&lang=fr\&site=ehostlive

Askildson, L. (2005). Effects of humor in the language classroom: Humor as a pedagogical tool in theory and practice. Working Papers in SLAT, 12, 45-61.

Azizinezhad, M., \& Hashemi, M. (2011). Humor: A pedagogical tool for language learners. Procedia Social and Behavioral Sciences, 30, 2093-2098. https://doi.org/10.1016/j.sbspro.2011.10.407

Carr, S. (2017). Ask the editor: How to use "learn" and "study".

https://www.learnersdictionary.com/qa/How-toUse-Learn-and-Study-

Darmansyah. (2012). Strategi pembelajaran menyenangkan dengan humor. Jakarta: Bumi Aksara.

Davis, J. M. (2014). Humor and its cultural context. In Davis, J. M., \& Chey, J., Humor in Chinese Life and Culture (Issue June 2013). Hong Kong: Hong Kong University

Press. https://doi.org/10.5790/hongkong/9789888139231. 003.0001

Farahani, A. A. K., \& Abdollahi, Z. (2018). Incorporating humor to develop EFL learner's speaking ability and willingness to communicate. Journal of Language Teaching and Research, 9(1), 205-211. https://doi.org/10.17507/jltr.0901.26

Fata, I. A., Komariah, E., \& Irfandy, I. (2018). Laugh and learn: Evaluating from students' perspective of humor used in English class. Al-Ta Lim Journal, $25(2)$, $117-127$ https://doi.org/10.15548/jt.v25i2.425

Glenn, P. J. (2003). Laughter in interaction. Cambridge University Press.

Hibatullah, O. F., \& Ardlillah, Q. F. (2019). "Give me a joke, please!": Creating a fun learning by Teachers' Jokes. PEOPLE: International Journal of Social Sciences, 5(2), 948-958. https://doi.org/10.20319/pijss.2019.52.948958

Jatiyasa, I. W. (2019). Implementasi Humor dalam Pembelajaran di STKIP Agama Hindu Amlapura. $e$ Jurnal Mitra Pendidikan, 3(1), 65-80.

Kristmanson, P. (2000). Affect: in the second language classroom: How to create an emotional climate. Reflexions, 19(2), 1-5.

Phakiti, A. (2006). Theoretical and pedagogical issues in ESL/EFL teaching of strategic reading. University of Sydney Papers in TESOL, 1(1), 19-50.

Pranoto B.E., \& Suprayogi. (2020). Incorporating 9GAG memes to develop EFL learners' speaking ability and willingness to communicate. IJEE (Indonesian Journal of English Education), 7(2), 130-144. doi:10.17496 /ijee.v7i2.17496

Provine, R. (2002). The science of laughter. Psychology Today, 33 (6), 58-62.

Syafiq, A. N. (2012). Humor English teaching material for improving students' speaking skill with high and low learning motivation. Language Circle: Journal of Language and Literature, 7(1), 45-54. https://doi.org/10.15294/lc.v7i1.2431

Wagner, M., \& Urios-Aparisi, E. (2011). The use of humor in the foreign language classroom: Funny and effective? Humor, 24(4), 399-434. https://doi.org/10.1515/HUMR.2011.024 